\author{
ARKADIUSZ KOSMALA \\ ADAM AUGUSTYNIAK ${ }^{1}$ \\ DAWID PERLIKOWSKI ${ }^{1}$ \\ IZABELA PAWLOWICZ ${ }^{1}$ \\ WLODZIMIERZ ZWIERZYKOWSKI ${ }^{1}$ \\ AGNIESZKA PLAŻEK ${ }^{2}$ \\ EUGENIUSZ PASZKOWSKI ${ }^{3}$ \\ ${ }^{1}$ Instytut Genetyki Roślin Polskiej Akademii Nauk \\ ${ }^{2}$ Uniwersytet Rolniczy w Krakowie \\ ${ }^{3}$ DANKO Hodowla Roślin \\ Kierownik Tematu: dr hab. Arkadiusz Kosmala Instytut Genetyki Roślin Polskiej Akademii Nauk \\ Strzeszyńska 34,60-479 Poznań, tel. 61 6550285, e-mail: akos@igr.poznan.pl
}

Prace zostały wykonane $w$ ramach badan podstawowych na rzecz postępu biologicznego $w$ produkcji roślinnej na podstawie decyzji Ministra Rolnictwa $i$ Rozwoju Wsi nr HOR.hn.802.18.2018, Zadanie nr 35.

\title{
Identyfikacja genów związanych z ekspresją zimotrwałości i tolerancji suszy u form introgresywnych Lolium multiflorum/Festuca arundinacea
}

\section{Identification of genes associated with winter-hardiness and drought tolerance in the introgression forms of Lolium multiflorum/Festuca arundinacea}

Słowa kluczowe: cor14b, mrozoodporność, odporność na choroby, odporność na suszę, trawy, Wcor80, zimotrwałość

\section{CEL PODJETEGO TEMATU I PROWADZONYCH BADAŃ}

Trawy pastewne, a pośród nich kostrzewy (Festuca) i życice (Lolium) są doskonałymi gatunkami do badań molekularnej kontroli cech związanych z tolerancją stresów środowiskowych. Lolium multiflorum Lam. (życica wielokwiatowa) to gatunek trawy o wysokiej jakości paszowej, lecz niskiej tolerancji stresów abiotycznych i biotycznych. $Z$ kolei $F$. pratensis Huds. (kostrzewa łąkowa) i $F$. arundinacea Schreb. (kostrzewa trzcinowa) - charakteryzują się wysokim stopniem odporności na patogeny oraz tolerancji mrozu, suszy i wysokiego zasolenia (Kosmala i in., 2006, 2009, 2012). Gatunki Lolium i Festuca krzyżują się ze sobą. Stwarza to możliwość przeniesienia korzystnych 
cech z gatunków jednego rodzaju do gatunków drugiego rodzaju na drodze krzyżowania. Alloheksaploidalny gatunek $F$. arundinacea wykorzystywany jest głównie jako źródło genów tolerancji suszy (Kosmala i in. 2012; Perlikowski i in., 2016 a, b; Augustyniak $\mathrm{i}$ in., 2018). Festuca pratensis jest z kolei gatunkiem wykorzystywanym jako źródło genów tolerancji mrozu (Kosmala i in., 2006, 2009). Wykazano również, że dzięki obecności sub-genomu kostrzewy łąkowej w genomie kostrzewy trzcinowej, ten drugi gatunek może być także doskonałym źródłem genów odpowiedzialnych za zimotrwałość, w tym mrozoodporność (Kosmala i in., 2007; Augustyniak i in., 2018). W niniejszym zadaniu badawczym prowadzone są prace zmierzające do selekcji genotypów, które wykazują stosunkowo wysoki poziom tolerancji sekwencji stresów susza/zima i odporności na podstawowe choroby oraz do wyznaczenia fizjologicznych i molekularnych wskaźników tolerancji/odporności na analizowane stresy abiotyczne i biotyczne. Odporność na suszę jest cechą poligeniczną i wielokomponentową. Na szczególną uwagę w przypadku badania mechanizmów tej odporności u roślin zasługują jej trzy główne komponenty - unikanie suszy (ang. drought avoidance), tolerancja suszy (ang. drought tolerance) i regeneracja po ustąpieniu warunków stresowych (ang. recovery). W niniejszym zadaniu badawczym analizowano wszystkie trzy komponenty odporności na suszę. Ważnym czynnikiem wpływającym na plonowanie roślin jest również potencjał ich odporności na stresy biotyczne, w tym choroby grzybowe i wirusowe (Płażek i in., 2018). Podstawowe cele badań w roku 2018 obejmowały:

— analizę profilu akumulacji transkryptów, kodujących Cor14b dla dwóch wyselekcjonowanych form introgresywnych L. multiflorum/F. arundinacea, różniących się potencjałem mrozoodporności,

— analizę profilu akumulacji białek Wcor80 i Cor14b dla dwóch wyselekcjonowanych form introgresywnych L. multiflorum/F.arundinacea, różniących się potencjałem mrozoodporności,

— przeprowadzenie testów tolerancji suszy polowej w eksperymencie „pod daszkami” form introgresywnych (BC6),

- ocenę stopnia podatności roślin na podstawowe choroby ( $w$ okresie letnim i jesiennym).

Materiał badawczy do analiz molekularnych (ekspresja genu corl4b i poziom akumulacji białek Wcor80 i cor14b) stanowiły dwie formy introgresywne pokolenia BC5 L. multiflorum $/ F$. arundinacea wyselekcjonowane w roku 2015 - forma o stosunkowo wysokim potencjale mrozoodporności (180/30/138) i forma o stosunkowo niskim potencjale odporności (180/30/19). Analizy prowadzono w 5 punktach czasowych: warunki kontrolne, 3, 7, 14 i 21 dzień hartowania na mróz (cele badawcze nr 1 i 2). Materiał badawczy do realizacji celu nr 3 i 4 stanowiły cztery populacje form introgresywnych pokolenia BC6 L. multiflorum/F. arundinacea $(185 / 4,6,10$ i 12) oraz populacja roślin kontrolnych L. multiflorum odm. Atos. 


\section{OPIS WYNIKÓW}

Uzyskano dwa profile akumulacji transkryptu dla genu corl $4 b$ — jeden dla formy introgresywnej 180/20/138 i jeden dla formy introgresywnej 180/30/19. W trakcie trwania hartowania na mróz obserwowano stopniowy wzrost ekspresji genu corl4b u obu analizowanych form, aż do piątego dnia hartowania. Następnie obserwowano spadek poziomu akumulacji transkryptu. W trakcie hartowania na mróz, poziom transkrypcji genu cor $14 b$ był zawsze wyższy u formy introgresywnej 180/30/138.

Uzyskano cztery profile akumulacji białek: (i) dwa profile akumulacji białka Wcor80 jeden dla formy introgresywnej 180/20/138 i jeden dla formy introgresywnej 180/30/19 oraz (ii) dwa profile akumulacji białka Cor14b. Zaobserwowano istotne różnice międzygenotypowe w poziomie akumulacji białek Wcor80 i Cor14b u form introgresywnych o różnym poziomie mrozoodporności.

Na podstawie średnich wartości badanych parametrów plonowania dla poszczególnych populacji, stwierdzono, że najwyższym potencjałem tolerancji warunków suszy cechowała się populacja form introgresywnych 185/4 (bonitacja 6,1; sucha masa 11,2 g; zielona masa $69,5 \mathrm{~g}$ ). Natomiast najniższym stopniem tolerancji - populacja form introgresywnych 185/12 (bonitacja 4,3; sucha masa 6,9 g; zielona masa 41,5 g). Średnie parametry plonowania uzyskane dla populacji 185/12 były istotnie niższe w odniesieniu do średnich parametrów plonowania uzyskanych dla populacji form kontrolnych L. multiflorum odm. Atos (bonitacja 4,7; sucha masa $9,1 \mathrm{~g}$; zielona masa 49,3 g). Pozostałe dwie badane populacje form introgresywnych, 185/6 i 185/10, cechowały się średnimi wyższymi w odniesieniu do populacji roślin kontrolnych, lecz niższymi w stosunku do populacji 185/4. Jednocześnie obserwowano stosunkowo szeroki zakres tolerancji warunków suszy w obrębie poszczególnych analizowanych populacji roślin.

$\mathrm{W}$ czerwcu na roślinach uprawianych $\mathrm{w}$ namiotach odnotowano występowanie głównie mączniaka traw. Porażenie to nie było duże, głównie w stopniu 1 i 2, w skali $0-5$. W roku 2018 odnotowano zdecydowanie więcej przypadków porażenia wirusem (98 roślin), powodującym żółte smugi liści, w porównaniu do lat wcześniejszych, ale porażenie to występowało tylko w stopniu 1-2; u kilku roślin w stopniu 3 i 4.

Na podstawie średnich wartości badanych parametrów plonowania dla poszczególnych populacji, stwierdzono, że najwyższym potencjałem regeneracji po ustąpieniu suszy cechowała się populacja form introgresywnych 185/4 (odrost 4,4; sucha masa 5,9 g; zielona masa $35,8 \mathrm{~g}$ ). Natomiast najniższym stopniem regeneracji — populacja form introgresywnych 185/12 (odrost 2,2; sucha masa 1,7 g; zielona masa 10,6 g). Średnie parametry plonowania uzyskane dla populacji $185 / 12$ były istotnie niższe w odniesieniu do średnich parametrów plonowania uzyskanych dla populacji form kontrolnych L. multiflorum odm. Atos (odrost 2,3; sucha masa 1,8 g; zielona masa 10,7 g). Pozostałe dwie badane populacje form introgresywnych, 185/6 i 185/10, cechowały się średnimi wyższymi w odniesieniu do populacji roślin kontrolnych, lecz niższymi w stosunku do populacji 185/4. Jednocześnie obserwowano stosunkowo szeroki zakres regeneracji roślin po ustąpieniu warunków suszy w obrębie poszczególnych analizowanych populacji. Ponadto, w każdej z badanych 
populacji roślin były genotypy zarówno o stosunkowo wysokim poziomie regeneracji po ustąpieniu warunków suszy, jak i genotypy o stosunkowo niskim poziomie regeneracji.

Druga ocena porażenia przeprowadzona jesienią (po wtórnym nawodnieniu) nie wykazała również, podobnie jak latem, występowania ostrych objawów chorobowych. Rośliny uprzednio traktowane suszą wykazywały niewielkie porażenie mączniakiem i plamistościami liści (ocena wahała się w granicach 1-3), natomiast w ogóle nie występowała na nich rdza. Zaobserwowane objawy wskazywały na sporadyczne występowanie na badanych roślinach takich grzybów, jak Drechslera siccans, D. dictyoides oraz Bipolaris sorokiniana.

\section{WNIOSKI Z PROWADZONYCH BADAŃ}

1. Profile relatywnej ekspresji genu cor $14 b \mathrm{w}$ warunkach hartowania na mróz mogą być dobrym markerem tolerancji niskiej temperatury $\mathrm{u}$ form introgresywnych L. multiflorum $/ F$. arundinacea.

2. Profile akumulacji białek Cor14b i Wcor80 w warunkach hartowania mogą być również dobrym markerem tolerancji niskiej temperatury $\mathrm{u}$ badanych form introgresywnych.

3. Wyselekcjonowano formy introgresywne $\mathrm{BC}_{6} \quad L$. multiflorum/F. arundinacea o wysokim potencjale tolerancji suszy, regeneracji metabolizmu po ustąpieniu warunków suszy i odporności na choroby.

\section{LITERATURA}

Augustyniak A., Perlikowski D., Rapacz M., Kościelniak J., Kosmala A. 2018. Insight into cellular proteome of Lolium multiflorum/Festuca arundinacea introgression forms to decipher crucial mechanisms of cold acclimation in forage grasses. Plant Sci. 272: $22-31$.

Kosmala A., Bocian A., Rapacz M., Jurczyk B., Zwierzykowski Z. 2009. Identification of leaf proteins differentially accumulated during cold acclimation between Festuca pratensis plants with distinct levels of frost tolerance. J. Exp. Bot. 60: $3595-3609$.

Kosmala A., Perlikowski D., Pawłowicz I., Rapacz M. 2012. Changes in the chloroplast proteome following water deficit and subsequent watering in a high and a low drought tolerant genotype of Festuca arundinacea. J. Exp. Bot. 63: $6161-6172$.

Kosmala A., Zwierzykowski Z., Gąsior D., Rapacz M., Zwierzykowska E., Humphreys M.W. (2006). GISH/FISH mapping of genes for freezing tolerance transferred from Festuca pratensis to Lolium multiflorum. Heredity 96: $243-251$.

Kosmala A., Zwierzykowski Z., Zwierzykowska E., Łuczak M., Rapacz M., Gąsior D., Humphreys M. W. 2007. Introgression-mapping of the genes for winter hardiness and frost tolerance transferred from Festuca arundinacea into Lolium multiflorum. J. Hered. 98: $311-316$.

Perlikowski D., Kierszniowska S., Sawikowska A., Krajewski P., Rapacz M., Eckhardt Ä., Kosmala A. 2016. Remodeling of leaf cellular glycerolipid composition under drought and re-hydration conditions in grasses from the Lolium-Festuca complex. Front. Plant Sci. 7:1027. DOI: 10.3389/fpls.2016.01027.

Perlikowski D., Czyżniejewski M., Marczak Ł., Augustyniak A., Kosmala A. 2016. Water deficit affects primary metabolism differently in two Lolium multiflorum/Festuca arundinacea introgression forms with a distinct capacity for photosynthesis and membrane regeneration. Front. Plant Sci. 7:1063. DOI: 10.3389/fpls.2016.01063.

Płażek A., Pociecha E., Augustyniak A., Masajada K., Dziurka M., Majka J., Perlikowski D., Pawłowicz I., Kosmala A. 2018. Dissection of resistance to Microdochium nivale in Lolium multiflorum/Festuca arundinacea introgression forms. Plant Physiol. Biochem. 123: $43-53$. 